\title{
New Insights into Tumor-Infiltrating B Lymphocytes in Breast Cancer: Clinical Impacts and Regulatory Mechanisms
}

\author{
Meng Shen ${ }^{1,2,3,4,5}$, Jian Wang ${ }^{1,2,3,4,5}$ and Xiubao $\operatorname{Ren}^{1,2,3,4,5,6 *}$ \\ 'Department of Immunology, Tianjin Medical University Cancer Institute and Hospital, Tianjin, China, ${ }^{2}$ National Clinical \\ Research Center for Cancer, Tianjin, China, ${ }^{3}$ Key Laboratory of Cancer Prevention and Therapy, Tianjin, China, \\ ${ }^{4}$ Tianjin's Clinical Research Center for Cancer, Tianjin, China, ${ }^{5}$ Key Laboratory of Cancer Immunology and Biotherapy, \\ Tianjin, China, ${ }^{6}$ Department of Biotherapy, Tianjin Medical University Cancer Institute and Hospital, Tianjin, China
}

OPEN ACCESS

Edited by:

Ana María Hernández, Center of Molecular Immunology (CIM), Cuba

Reviewed by: Kay L. Medina, Mayo Clinic Minnesota, United States Kang Chen,

Wayne State University, United States

${ }^{*}$ Correspondence: Xiubao Ren renxiubao@tjmuch.com

Specialty section: This article was submitted to B Cell Biology,

a section of the journal

Frontiers in Immunology

Received: 17 December 2017 Accepted: 21 February 2018 Published: 08 March 2018

Citation: Shen M, Wang $J$ and Ren X (2018) New Insights into Tumor-Infiltrating B Lymphocytes in Breast Cancer:

Clinical Impacts and Regulatory Mechanisms.

Front. Immunol. 9:470. doi: 10.3389/fimmu.2018.00470
Currently, tumor-infiltrating B lymphocytes have been recognized as a new hallmark of breast cancer (BC). The function seems to be controversial, either with positive, negative, or no significance in BC's prediction and prognosis. Moreover, B-cell infiltrates regulate tumor process through productions of antibodies and interleukin-10. The interactions with other lymphocytes and programmed death-1/PD-1 ligand axis are also documented. The regulatory mechanisms will eventually be incorporated into diagnostic and therapeutic algorithms, thus give guide to clinical treatment. In this review, we give new insights into clinical impacts and regulatory mechanisms of tumor-infiltrating B cells, which heralds a new era in immuno-oncology in BC treatment.

Keywords: tumor-infiltrating B lymphocytes, breast cancer, prognosis, regulatory mechanism, checkpoint molecules

\section{INTRODUCTION}

Breast cancer (BC) is a major worldwide health burden, which is linked with increased prevalence of malignancy-related mortality mostly among females (1). Current evidence demonstrated that the intensity of tumor immune response may influence the effectiveness of $\mathrm{BC}$ therapy, and probably affect clinical outcomes. However, the roles of tumor-infiltrating B cells (TIL-B) and plasma cells (PC) in cancer therapy still merit future investigations. Neither histopathological features nor conventional biomarkers are accurately described the predictive and prognostic roles of TIL-B in BC patients.

The regulatory mechanisms of TIL-B in BC process remain largely unknown. The release of antibodies (Abs) and cytokine interleukin (IL)-10 might be involved in TIL-B-mediated tumor immunity. Furthermore, the interactions of TIL-B with other lymphocytes and the programmed

Abbreviations: BC, breast cancer; OS, overall survival; TILs, tumor-infiltrating lymphocytes; TIL-B, tumor-infiltrating B cells; Bregs, regulatory B cells; Tregs, regulatory T cells; PD-1, programmed death-1; PD-L1, PD-1-ligand; pCR, pathologic complete response; NCT, neoadjuvant chemotherapy; BCSS, breast cancer specific survival; DFI, disease-free interval; RFS, recurrence-free survival; DFS, disease-free survival; TNBC, triple-negative breast cancer; MC, medullary carcinomas; PFS, progression-free survival; DCIS, ductal carcinoma in situ; mTIL, metastasis infiltrating lymphocytes; PT, primary tumors; TLS, tertiary lymphoid structure; ICIs, immune checkpoint inhibitors; ER, estrogen receptor; PR, progesterone receptor; CTL, cytotoxic T cells; ROC, receiver operator characteristics; GrB, Granzyme B; Ab, antibody; AUC, area under the curve; TAA, tumor-associated antigens; ADCC, antibody-dependent cell-mediated cytotoxicity; MUC1, polymorphic epithelial mucin. 
death-1 (PD-1)/PD-1-ligand (PD-L1) axis $(2,3)$ were also well documented. Immunotherapies with agents preventing the binding of the immune checkpoint PD-1 to PD-L1 was found to be efficacious in $\mathrm{BC}(4,5)$, which support a great need to fully understand the variations in TIL-B-mediated responses. Our objective is to highlight both pro- and antitumor effects of TIL-B, and underscore the regulatory mechanisms of TIL-B in the tumor environment.

\section{THE CLINICAL EFFICACY OF TIL-B IN BC}

Heavy B-cell infiltrates in breast carcinoma tissues is documented and appears to be associated with a more favorable or poorer prognosis. Clinical experiments involving immunohistochemistry for analyzing the predictive and prognostic significance of TIL-B was shown in Table 1.

\section{The Positively Predictive or Prognostic Value of TIL-B in BC The Positively Predictive Value}

As for BC patients with neoadjuvant chemotherapy (NCT) treatment, $\mathrm{CD} 20^{+} \mathrm{B}$ cell infiltrates could predict pathologic complete response (pCR) $(P=0.005$; OR, 1.80; 95\% CI, 1.19-2.72) in univariate analysis. In multivariable analysis, only CD20 independently predicted pCR $(P=0.0186$; OR, 5.368; $95 \%$ CI, 1.32-21.8), which indicated the predictive value of TIL-B through an independent manner (6). The effect was independent of age, size, nuclear grade, nodal status, estrogen receptor (ER), progesterone receptor (PR), HER2 status, and Ki67 score, which was different from other kinds of TILs. Another study also showed that in triple-negative breast cancer (TNBC) patients with NCT (7), CD20 cell density was found to be a predictor of pCR $(P=0.037 ; \mathrm{HR}, 1.004 ; 95 \% \mathrm{CI}, 1.000-1.007)$. According to the aforementioned studies, posttreatment profile of high $\mathrm{CD} 20^{+}$ $\mathrm{B}$-cell infiltrates might identify a highly responsive group of $\mathrm{BC}$ patients. Most importantly, it supported the predictive impact of chemotherapy-mediated immune changes and identified a high-risk post-NCT tumor B-cell infiltrates condition. Moreover, TIL-B was found to predict pCR both in pre- $(P=0.001)$ and post-NCT $(P=0.005)$ settings $(8)$, which enabled the predictive efficacy of B cells. As for the intratumoral transcript levels of TILB, B-cell metagenes served as an independent factor (9) which provided additional predictive information in carcinomas with high proliferative activity (HR, 0.66; 95\% CI, 0.46-0.97).

In the aspect of stromal lymphocytic infiltrates, Denkert et al. (10) suggested that $\mathrm{CD} 20^{+} \mathrm{B}$ cells were significantly linked to pCR $(P<0.0005)$ in a total of 1,058 post-NCT BC core biopsies. Interestingly, for women with benign breast disease (11), the absence of $\mathrm{CD} 20^{+}$cells versus the presence in all lobules showed an adjusted OR of 5.7 (95\% CI, 1.4-23.1) for subsequent cancer risk. The reduced B-cell infiltration in women with later BC suggested a role for $\mathrm{B}$ cells in preventing disease progression and serving as a potential biomarker for BC risk.

\section{The Positively Prognostic Value}

As for the prognostic effect of TIL-B (12), higher total number of $\mathrm{CD} 20^{+}$cell infiltrates, irrespective of location, was associated with significantly better breast cancer specific survival (BCSS) $(P=0.037)$ and longer disease-free interval (DFI) $(P=0.001)$ independently. A positive correlation was observed between higher $\mathrm{CD} 20^{+} \mathrm{B}$ cells number and higher tumor grade ( $\mathrm{rs}=0.20$, $P<0.001)$ and ER and PR negativity $(P<0.001)$. Moreover, Mohammed et al. (13) demonstrated in invasive ductal BC patients, tumor $\mathrm{CD}_{2} 0^{+}$infiltrates meant a longer BCSS, while CD $138^{+}$B-cell exerted an opposite effect. Collectively, a current meta-analysis (14) concluded that $\mathrm{CD} 20^{+} \mathrm{B}$ cells were associated with better BCSS (HR, 0.77; 95\% CI, 0.61-0.96) and disease-free survival (DFS) (HR, 0.72; 95\% CI, 0.58-0.89). The two studies discussed above $(12,13)$ were included. Recently, Xu et al. (15) showed that for all types of BC patients, high $\mathrm{CD} 20^{+} \mathrm{B}$ cells infiltrates predicted prolonged overall survival (OS) and DFS $(P<0.05)$. However, no differences of B-cell infiltrates (16) were noted in patients with or without lymph node metastasis. Considering the limited number of patients involved $(n=23)$, future researches are expected to explore the prognostic efficacy of TIL-B in BC environment.

As for the intratumoral transcript levels of TIL-B in BC, a multivariate analysis (9) confirmed the prognostic influence of the B-cell metagene in a cohort enriched for high-grade tumors and another for younger patients. As a result, in untreated, node-negative $\mathrm{BC}$ patients, B-cell-related mRNA transcripts indicated a good prognosis. TNBC, a subtype with robust immune cell infiltrates, is associated with a prognostic gene signature that including B cells. Rody et al. (17) revealed that the metagene signature involving $\mathrm{B} / \mathrm{PC}$ components was associated with improved survival in TNBC. As referred to above, a ratio of high B-cell and low IL- 8 metagenes served as the single significant predictor to identify $32 \%$ of overall 579 TNBC patients with good prognosis $(P<0.001)$. Specifically, better prognosis was observed for high B-cell/low IL-8 group in both untreated $(P=0.001)$ and post- chemotherapy patients $(P=0.05)$. Additionally, the B-cell signature exerted predictive values in TNBC when combined with other 26-gene TNBC-derived prognostic signatures (18). In receiver operator characteristics analyses, the area under the curve (AUC) for the $\mathrm{B}$-cell metagene was $0.606(P=0.025)$ and for the 26-gene signature was $0.588(P=0.061)$. A simple linear combination of both scores led to an improved AUC of $0.656(P=0.001)$. Furthermore, in the evaluation of prognostic potentials in NCT, Alistar et al. (19) indicated that B/PC metagenes were positively associated with distant metastasis-free survival. The protective effect, however, was mostly restricted to highly proliferative cancers of basal-like, HER2-enriched and luminal B subtypes. The results were consistent with Nagalla et al's research (20). All factors pointed to the predictive roles of TIL-B in BC prognosis, and emphasized the improved efficacy when combined with other TILs. However, when referred to different BC subtypes (21), the prognostic value of the B-cell/IL-8 ratio was mainly confined to the basal-like and TNBC subtypes. Recent studies utilized mRNA sequencing to analyze whether B-cell could be prognostic within specific BC subtypes. Improved metastasisfree/progression-free survival (22) was correlated with high B-cell gene signatures, which were found in basal-like and HER2-enriched subtypes. 
TABLE 1 | Clinical experiments involving predictive or prognostic significance of tumor-infiltrating B cells in BC.

\begin{tabular}{|c|c|c|c|c|c|c|c|}
\hline Year & Reference & Patients & Treatment & $\begin{array}{l}\text { Surface } \\
\text { marker }\end{array}$ & $\begin{array}{l}\text { Predictive } \\
\text { efficacy }\end{array}$ & Clinical outcomes & $\begin{array}{l}\text { Independent } \\
\text { predictive/ } \\
\text { prognosis factor }\end{array}$ \\
\hline \multicolumn{8}{|c|}{ Positively predictive or prognostic significance } \\
\hline 2017 & Xu et al. (15) & 102 IDC & NR & CD20 & NR & $\begin{array}{l}\text { Improved OS and } \\
\text { DFS (data not shown) }\end{array}$ & NR \\
\hline 2017 & Song et al. (7) & $\begin{array}{l}108 \text { primary } \\
\text { TNBC }\end{array}$ & $\begin{array}{l}\text { Post-NCT } \\
\text { (anthracycline } \\
\text { and taxane-based) }\end{array}$ & CD20 & $\begin{array}{l}\text { pCR } \\
P=0.037, \mathrm{HR}: 1.004 \\
95 \% \mathrm{Cl}: 1.000-1.007\end{array}$ & $\begin{array}{l}\text { Not with DFS } \\
(P=0.194)\end{array}$ & NR \\
\hline 2014 & Brown et al. (6) & $\begin{array}{l}105 \text { invasive } \\
\text { BC }\end{array}$ & $\begin{array}{l}\text { Post-NCT } \\
\text { (anthracycline } \\
\text { and taxane-based) }\end{array}$ & CD20 & $\begin{array}{l}\text { pCR } \\
P=0.0053, \text { OR:1.80; } \\
\text { 95\% Cl: 1.19-2.72 } \\
\text { (univariate analysis) } \\
P=0.0186, \text { OR:5.36; } \\
\text { 95\% Cl: 1.32-21.8 } \\
\text { (multivariate analysis) }\end{array}$ & NR & $\begin{array}{l}\text { Independent } \\
\text { predictive } \\
\text { factor }\end{array}$ \\
\hline 2013 & $\begin{array}{l}\text { Mohammed } \\
\text { et al. (13) }\end{array}$ & $\begin{array}{l}338 \text { operable } \\
\text { IDC }\end{array}$ & $\begin{array}{l}\text { Adjuvant therapies } \\
\text { (chemo-, hormonal } \\
\text { and radiotherapy) }\end{array}$ & CD20 & NR & Better BCSS $(P<0.01)$ & NR \\
\hline 2012 & $\begin{array}{l}\text { Mahmoud } \\
\text { et al. (12) }\end{array}$ & $\begin{array}{l}1,470 \text { primary } \\
\text { invasive } B C\end{array}$ & $\begin{array}{l}\text { Standard surgical of } \\
\text { mastectomy/excision } \\
\text { with radiotherapy }\end{array}$ & CD20 & NR & $\begin{array}{l}\text { Better BCSS }(P=0.037) \\
\text { Longer DFI }(P=0.001)\end{array}$ & $\begin{array}{l}\text { Independent } \\
\text { prognosis } \\
\text { factor }\end{array}$ \\
\hline 2010 & $\begin{array}{l}\text { Denkert } \\
\text { et al. (10) }\end{array}$ & $1,058 \mathrm{BC}$ & $\begin{array}{l}\text { Post-NCT } \\
\text { (anthracycline } \\
\text { and taxane-based) }\end{array}$ & CD20 & $\mathrm{pCR} P<0.0005$ & NR & NR \\
\hline
\end{tabular}

Negatively prognostic significance

\begin{tabular}{|c|c|c|c|c|c|c|c|}
\hline 2017 & $\begin{array}{l}\text { Miligy } \\
\text { et al. (24) }\end{array}$ & $\begin{array}{l}80 \text { DCIS } \\
\text { (36 pure and } \\
44 \text { with IDC) }\end{array}$ & $\begin{array}{l}\text { Adjuvant therapies } \\
\text { based on risk } \\
\text { stratification }\end{array}$ & $\begin{array}{l}\text { CD19, CD20, } \\
\text { CD138 }\end{array}$ & NR & Shorter RFS $(P=0.04)$ & $N R$ \\
\hline 2013 & $\begin{array}{l}\text { Mohammed } \\
\text { et al. (13) }\end{array}$ & $\begin{array}{l}338 \text { operable } \\
\text { IDC }\end{array}$ & $\begin{array}{l}\text { Adjuvant therapies } \\
\text { (chemotherapy, } \\
\text { hormonal therapy, } \\
\text { and radiotherapy) }\end{array}$ & $\begin{array}{l}\text { Plasmacells; } \\
\text { CD138 }\end{array}$ & NR & $\begin{array}{l}\text { Shorter RFS } \\
\text { Plasma cells-HR: } 2.96 \\
\text { 95\% Cl: } 0.17-0.50, P<0.001 \\
\text { CD138-HR:1.92, Cl: } \\
1.37-2.68, P<0.001\end{array}$ & $N R$ \\
\hline 2012 & $\begin{array}{l}\text { Mohammed } \\
\text { et al. (26) }\end{array}$ & 468 IDC & $\begin{array}{l}\text { Adjuvant therapies } \\
\text { (chemo-, hormonal, } \\
\text { and radiotherapy) }\end{array}$ & Plasmacells & NR & $\begin{array}{l}\text { Shorter RFS } \\
\text { (ER-negative: HR 3.25; } \\
\text { 95\% Cl: 1.75-6.04, } P<0.001 \text {; } \\
\text { ER-positive: HR 3.53; 95\% Cl: } \\
\text { 1.97-6.29, } P<0.001 \text { ) }\end{array}$ & $\begin{array}{l}\text { Independent } \\
\text { prognosis } \\
\text { factor }\end{array}$ \\
\hline
\end{tabular}

\section{No predictive or prognostic significance}

\begin{tabular}{|c|c|c|c|c|c|c|c|}
\hline 2016 & $\begin{array}{l}\text { Thompson } \\
\text { et al. (35) }\end{array}$ & $\begin{array}{l}27 \text { DCIS } \\
\text { (24 pure and } \\
3 \text { with IDC) }\end{array}$ & NR & CD20 & NR & $\begin{array}{l}\text { Not with recurrence } \\
(P=0.45)\end{array}$ & NR \\
\hline 2012 & Eiro et al. (33) & 102 early IDC & $\begin{array}{l}\text { Any type of } \\
\text { neoadjuvant } \\
\text { therapies }\end{array}$ & CD20 & NR & $\begin{array}{l}\text { Not with RFS } \\
(P=0.956)\end{array}$ & NR \\
\hline 2011 & West et al. (32) & $\begin{array}{l}113 \text { ER-negative } \\
\text { invasive BC }\end{array}$ & $\begin{array}{l}\text { NCT (anthracycline- } \\
\text { based) }\end{array}$ & CD20 & $\begin{array}{l}\text { Fail to predict } \mathrm{pCR} \\
(P>0.1)\end{array}$ & NR & NR \\
\hline 1994 & Scholl et al. (29) & $196 \mathrm{BC}$ & $N R$ & L26 (CD20) & NR & $\begin{array}{l}\text { Not with metastases } \\
\text { occurrence/poor } \\
\text { survival (data not shown) }\end{array}$ & NR \\
\hline
\end{tabular}

BC, breast cancer; NCT, neoadjuvant chemotherapy; pCR, pathologic complete response; BCSS, breast cancer specific survival; DFI, disease-free interval; DFS, disease-free survival; NR, not reported; ER, estrogen receptor; PR, progesterone receptor; TNBC, triple-negative breast cancer; OS, overall survival; OR, odds ratio; HR, hazard ratio; IDC, invasive ductal breast cancer; DCIS, ductal carcinoma in situ; RFS, recurrence-free survival. 


\section{The Negatively Prognostic Value of TIL-B in BC}

In addition to the positive function of TIL-B on antitumor reactions, compelling evidence suggests TIL- $B$ may be associated with a worse prognosis of BC patients (shown in Table 1). In 134 cases of invasive $\mathrm{BC}$ and 31 breast fibroadenoma (23), the density of $\mathrm{CD} 19^{+} \mathrm{B}$ cells were positively associated with histological grade III, lymph node metastasis, TNM stage T4, and ER/PR negative status (indicators of poor prognosis). In particular, a significant association between CD19+ $\mathrm{B}$-cell frequency and a small tumor size was also noticed $(P=0.021)$. To date, in tumors with mixed breast ductal carcinoma in situ (DCIS) (24), high density B-cell was linked to variables of poor prognosis referred to above. Outcome analysis revealed that pure DCIS with higher B-cell infiltrates presented shorter RFS $(P=0.04)$. However, no significant association was found in $\mathrm{CD} 138^{+} \mathrm{PC}$ count $(P=0.07)$. Other cases suggested that the predictive efficacy of PCs infiltration remains largely controversial. Of note, Parkes et al. (25) demonstrated that the presence of PCs, defined by infiltrating cells that expressed high levels of immunoglobulin (Ig) K-chain mRNA, indicated a poor prognosis. Another study also suggested (26) PCs infiltrate were related to poorer RFS, which was irrelevant to ER situation. In 338 ductal BC patients (13), tumor PCs and $\mathrm{CD} 138^{+} \mathrm{B}$-cell infiltrates were both associated with poorer BCSS $(P<0.001)$ and poorer RFS $(P<0.001)$. Furthermore, another subset of $\mathrm{BC}$ termed PC-predominant $\mathrm{BC}$ (PPBC) (27) was found to indicate worse OS (HR, 2.686; $P=0.038)$ than patients with non-PPBC. All data indicated the potential prognostic efficiency of PCs infiltration, which merit future investigations.

Interestingly, TILs (28) in the metastatic lesions displayed a similar arrangement as their matched primary tumors (PT), containing $\mathrm{CD}^{+} \mathrm{T}$ cells being most abundant followed by $\mathrm{CD}^{+}$ $\mathrm{T}$ cells and $\mathrm{CD} 20^{+} \mathrm{B}$ cells. Only patients with brain metastases differed by owning less $\mathrm{CD} 20^{+} \mathrm{B}$ cells at the infiltrative margin $(P<0.05)$. It further underlined that decreasing number of $\mathrm{CD} 20^{+} \mathrm{B}$-cell might extend the aggressive behaviors of PT cancer cells metastasizing to the brain.

\section{No Predictive or Prognostic Value of TIL-B in BC}

In 1994, Scholl et al. emphasized (29) that there was no association between L26-positive B-cell infiltration and survival. Similarly, a weak tendency of correlations was observed between $\mathrm{CD} 20^{+} \mathrm{B}$ cells and histological grade, Ki67 and cyclin A (30), which concluded that TIL-B did not appear to influence death in node-negative BC. In invasive ductal carcinoma tissues (31), B cells were not correlated with patients' age, clinical, or histologic grades. No prognosis-related parameters were mentioned in the study. Another research (32) further suggested that B-cell genes failed to individually predict $\mathrm{pCR}$ $(P>0.1)$ in 113 ER-negative BC cases. However, they showed that anthracycline-based chemotherapy was to a certain extent more effective for $\mathrm{CD} 20^{\text {high }}$ than for $\mathrm{CD} 20^{\text {low }}$ patient group, suggesting a potential clinical utility of CD $20^{+}$TIL-B in predicting chemo-responsiveness. In post-chemotherapy residual tumor, no differences were found for B-cell infiltrates with DFS (8). In similar, Eiro et al. indicated that there was no prognostic value of CD20+ TIL-B alone (33), but high CD68/(CD3 plus CD20) ratio served as an independent factor in predicting shorter distant RFS $(P<0.01)$. Among TNBC patients treated with NCT (7), no significant correlation was found with DFS situation $(P=0.194)$. These findings proved that to some extent, TIL-B were not a valuable tool for predicting $\mathrm{BC}$ prognosis in routine pathology practice (Table $\mathbf{1}$ ).

As for DCIS, the frequency of CD20+ B cells was significantly higher in high-grade DCIS patients (34) and was associated with high-risk features. However, there was no sign of recurrence risk prediction. This was consistent with a published research by Thompson et al. (35), who found a trend for elevated numbers of $\mathrm{CD} 20^{+}$in ER-negative versus ER-positive DCIS cases, but $\mathrm{CD} 20^{+}$cells were not associated with recurrence $(P=0.45)$. Overall, there is great need to further prove the clinical utility of TIL-B and explore the correlations between TIL-B and BC prognosis.

\section{THE REGULATORY MECHANISMS OF TIL-B IN BC}

Several studies focused on the aspect of TIL-B and the specific mechanisms within the overall tumor microenvironment, which are summarized in Figure 1.

\section{Antibodies Secretion}

In the tumor microenvironment, TIL-B can secret Abs against $\mathrm{BC}$ antigens, which are potent mechanisms of tumor control. To be more specific, antigens mainly including $\beta$-actin and ganglioside GD3, which were derived from cancer cells, could be recognized by TIL-B (36-38). In medullary carcinomas (MC), TIL-B-derived auto-Abs were shown to recognize these antigens; hence, directed against an intracellular protein trans-located to the cell surface upon MC cell apoptosis. The apoptotic MC cells were shown to expose actin on cell surface, permitting its recognition by TIL-B-secreting auto-Abs (37). More specific, the TIL-B (36) in half of the MC patients mainly exhibited an IgG2 response, which was an antigen-derived early apoptotic event. The process can facilitate the translocation and proteolytic fragmentation of intracellular proteins. Another study (38) showed that the capacity of TIL-B was to reveal key cancer-related antigens, such as the GD3 ganglioside, which influenced tumor cell progression. In addition, IgG subtype secretion (39) can also facilitate DC-induced T-cell response; hence, prevent $\mathrm{BC}$ relapse (40). Activated 4T1 tumor-draining lymph node (TDLN) B cells secreted IgG in response to tumor cells through an immunologically specific manner. These activated B cells were capable of mediating specific lysis of tumor cells in vitro. Transfer of activated B cells alone inhibited spontaneous metastases of cancer cells to the lung. The transfer also resulted in the induction of tumor-specific T-cell immunity as measured by cytotoxicity and the productions of cytokine interferon (IFN)- $\gamma$ and granulocyte-macrophage 


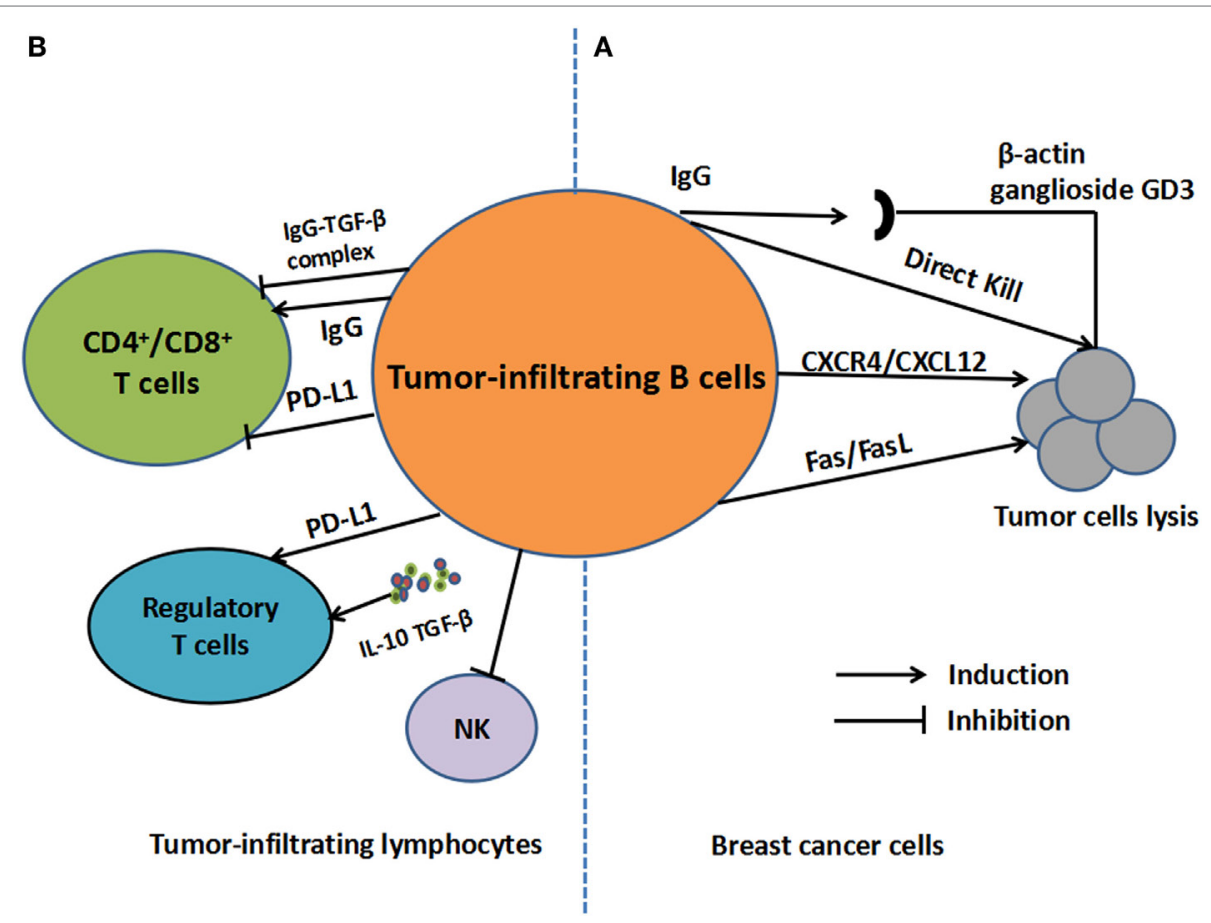

FIGURE 1 | The regulatory mechanisms of tumor-infiltrating B cells (TIL-B) in breast cancer. (A) For tumor cells, antigens including $\beta$-actin and ganglioside GD3, which are derived from cancer cells, can be recognized by TIL-B. TIL-B can also kill tumor cells directly. Moreover, TIL-B can kill cancer cells in CXCR4/CXCL12 pathways by cell-to-cell contact or through Fas/FasL pathways. (B) For other tumor-infiltrating lymphocytes, regulatory functions on regulatory $T$ cells may be engendered through secretion of IL-10 and transforming growth factor (TGF)- $\beta$ as well as overexpression of PD-1-ligand (PD-L1). As for T-cell response, IgG secretion can facilitate DC-induced T-cell response or inhibit cytotoxic T cells response in the form of IgG-TGF- $\beta$ complex. T cell inhibition by PD-L1 expression is also involved in the process.

colony-stimulating factor. In similar, TDLN B cells plus IL-2 administration (41) produced larger amounts of IgG, binding to $4 \mathrm{~T} 1$, and led to cancer cells lysis. The study also suggested that TDLN B cells could kill cancer cells in CXCR4/CXCL12 pathways by cell-to-cell contact, which termed to be an additive manner. The CXCR4 expression on B cells lead to cytotoxicity of CXCL12- producing tumor cells. Without cell contact, perforin also play a role in B cell-mediated tumor cell cytotoxicity in TDLN (41).

Antibodies binding to tumor antigens may induce powerful antitumor response, underscoring the essential roles of TIL-B in the $\mathrm{BC}$ environment. The production of $\mathrm{Abs}$ binding to specific tumor-associated antigens (TAA) on BC cells can trigger natural killer (NK) cells to bind to the Fc portion of Abs, resulting in tumor cell lysis through antibody-dependent cellmediated cytotoxicity (ADCC). In BC environment, ADCC is a vital immune mechanism sculpted by evolution to eradicate tumor cells, in which tumor cells can be recognized by tumor antigen-specific Abs. For example, a typical TAA termed polymorphic epithelial mucin (MUC1) was observed to play a role in BC immunity. Fremd et al. observed that high anti-MUC1 IgG levels were positively associated with improved OS in $\mathrm{BC}$ patients (42). A previous study (43) also concluded that in early stage BC, both serum MUC1 IgG and IgM Abs were associated with a significant benefit in disease-specific survival. The MUC1 Abs might further aid in the control of tumor dissemination and identify better clinical outcomes of BC patients. Currently, Gheybi et al. (44) proved that the recombinant HER2-MUC1 as a chimeric protein vaccination in a mouse model to develop a more efficacious vaccine against BC. These findings implied a critical role of MUC1 as a vital TAA in B-cell-mediated tumor immunity. In conclusion, a tumor antigen-specific immune response triggered by TIL-B may contribute to the regulations of BC immunity.

\section{IL-10 Production}

Within the tumor environment, regulatory B cells (Bregs) are widely recognized to inhibit immune responses through IL-10 production (45). However, the inner mechanisms of IL-10 secretion by TIL-B and the roles in breast tumor sites remained to be elaborately concluded. A typical type of $\mathrm{B} 220^{+} \mathrm{CD} 25^{\mathrm{hi}} \mathrm{CD} 69^{\mathrm{hi}} \mathrm{MHC}-\mathrm{II}^{\mathrm{hi}}$ B-cell subset (46) could promote lung metastases of BC, which secrete cytokine transforming growth factor (TGF)- $\beta$ and IL-10. The suppressive effect of $\mathrm{B}$ cells in the tumor setting was partly relied on IL-10 secretion. However, the primary role of TIL-B was to induce the conversion of $\mathrm{CD}^{+} \mathrm{T}$ cells to FoxP3 ${ }^{+}$regulatory $\mathrm{T}$ cells (Tregs) in a TGF- $\beta$-dependent manner. Additionally, Tao et al. (47) demonstrated IL-10-producing B cells derived from TDLN could kill BC cells through Fas/FasL pathways. IL-10 is an essential regulator in the process. The absence of IL-10 led to augmented therapeutic efficacy of adoptively transferred TDLN B cells. However, in EMT-6 murine models, mice that are 
genetically lacking in B cells (BCDM) showed a reduced tumor growth. The adopt transfer of wide type or IL-10-/- B cells both restored tumor growth and reduced survival relative to BCDM $(48,49)$, which suggested that IL-10 secretion may be not necessary in restoring tumor growth in murine models. As a result, the production of IL-10 might be partly involved in the regulatory mechanisms of B-cell infiltrates in PT or TDLN, which deserved future investigations.

\section{The Regulatory Effects on Other Lymphocytes}

Within the tumor environment, purified TIL-B (50) were reported to suppress the proliferation of $\mathrm{CD}^{+}, \mathrm{CD}^{+}$, and $\mathrm{CD} 4^{+} \mathrm{CD} 25^{-} \mathrm{T}$ cells, as well as $\mathrm{NK}$ proliferation in response to IL-15. Extensive B-cell infiltration demonstrated impaired cytotoxic T cells (CTL) response when compared with that in B-cell-deficient $\mu^{(--)}$mice. In EMT- 6 murine models, tumors show reduced growth in BCDM. The B-cell deficiency (49) was accompanied by increased $\mathrm{T}$ and $\mathrm{NK}$ cell infiltration, a more vigorous Th1 cytokine response, and an increased CTL response. In addition, a decreased number of $\mathrm{CD} 4^{+} \mathrm{CD} 25^{+} \mathrm{FoxP} 3^{+}$Tregs was noted in the spleen of BCDM and TDLN relative to wide-type mice. Consistent with these results, Zhang et al. demonstrated that high frequencies of intratumoral B cells were associated with increased recruitment and proliferation of Tregs (48). The accumulations of the two cells might contribute to reduced infiltrations of $\mathrm{NK}$ and $\mathrm{CD}^{+} \mathrm{T}$ cell in the tumor sites, resulting in an impaired T-cell response. Another typical Breg infiltrates (46) was able to induce the conversion of $\mathrm{CD}^{+} \mathrm{T}$ cells to FoxP3 ${ }^{+}$ Tregs in a TGF- $\beta$-dependent manner, which promoted lung metastases of BC. A previous study also proved B lymphocytes secreting IgG linked to latent TGF- $\beta$ to prevent CTL responses (51). However, a research demonstrated that the adoptive transfer of TDLN-derived B cells led to the enhanced tumor-specific T-cell response (40) with increasing productions of IFN- $\gamma$ and GM-CSF. It underscored the vital effect of TIL-B on T cellmediated immunity, which further resulted in the inhibition of 4T1 spontaneous pulmonary metastases. A atypical Granzyme B (GrB)-secreting B cells (52) termed CD $19^{+} \mathrm{CD} 20^{+} \mathrm{CD} 27^{-} \mathrm{CD} 38^{-}$ $\mathrm{IgD}^{-}$can upregulate several molecules interacting with other immune cells, including costimulatory, antigen-presenting, and the cell adhesion molecules, hence, might exert regulatory effects on other TILs. In addition, in BC patients, GrB (53) was highly expressed in one-third of the chemotherapy-treated tumors, and suggested an excessive CTL response within tumors after exposure to chemotherapy. The presence of GrB-secreting TIL-B might contribute to positively immune response in the tumor environment. The findings aforementioned indicated the collaborative interactions between TIL-B with other lymphocytes, which provided alternative strategies in developing more effective cellular therapies.

\section{The Interactions with PD-1/PD-L1 Axis}

Several studies have identified PD-L1 as a critical mediator of Bregs. Guan et al. (23) reported that PD-L1 contributed to the immunosuppressive role of $\mathrm{CD} 19^{+} \mathrm{CD} 24^{+} \mathrm{CD} 38^{+}$
Bregs in invasive BC patients. PD-L1 expression on B cells can result in the inhibition of T-cell proliferation (54) and T-cell-dependent immunogenic chemotherapy (51). The PD-L1 expression on B cells contributes to the B-cell suppressive properties, which may act as therapeutic targets for BC treatment.

Recent studies have indicated that an increased TILs presence at the tumor site is linked with the efficacy of immune checkpoint blockade (55). PD-L1 expression in BC was proved to be associated with poor prognosis (56). Clinical utility of immune checkpoint inhibitors (ICIs) has exerted long-lasting responses and survival benefits (57). However, their specific correlations with TIL-B and the acting mechanisms remain unclear. Patients with high B-cell infiltrates might benefit from ICIs treatment, and the underlying mechanisms are described as follows. Buisseret et al. suggested (58) that B-cell infiltrates in tumor tissue might be induced by immunotherapies targeting PD-1/PD-L1 axis. Specifically, PD-L1 expression was associated with higher TILs density including CD19+ $\mathrm{B}$ cells. TILs density, tertiary lymphoid structure, and PD-L1 expression were correlated with more aggressive tumor characteristics. These data emphasized the relationship between PD-1/PD-L1 expression and increased B-cell infiltration which represents a potential approach for antitumor treatment. Another similar study (23) observed that TIL-B were highly coincident with PD-L1 and IL-10 in invasive BC. Moreover, a typical subgroup of TIL-B termed $\mathrm{CD} 19^{+} \mathrm{CD} 24^{+} \mathrm{CD} 38^{+} \mathrm{B}$ cells can induce the formation of Tregs when cocultured with T cells from BC patients and healthy subjects ( 80.4 and $30.8 \%$, respectively). The regulatory process was proved to be mediated by PD-L1. In 4T1 murine BC models (50), PD-L1 expression was significantly increased in TIL-B relative to splenic $\mathrm{B}$ cells, which demonstrated enhanced inhibitory activity against $\mathrm{CD} 4^{+} / \mathrm{CD} 8^{+} \mathrm{T}$ cells and NK cells. It underlies the potential interactions between PD-L1 expression and inhibitory abilities of TIL-B. Together, these results were suggestive of a role for $\mathrm{CD} 19^{+} \mathrm{B}$ lymphocytes in immune suppression and tumor evasion via $\mathrm{PD}-\mathrm{L} 1$ in $\mathrm{BC}$.

\section{CONCLUSION}

Current evidence suggests that the B-cell infiltrates in BC tissues might perform either positive, negative, or none significant in humoral and cellular immunity of BC. Abs and IL-10-secreting $\mathrm{B}$ cells are involved in the process. Moreover, there are potential inter-connections between TIL-B with other lymphocytes and the efficacy of ICIs (Figure 1). Therapies targeting B-cell might contribute to an improvement in treatment efficacy. Additionally, other B cell-related mechanisms, such as the transcriptional regulations of TIL-B, can also be a promising option to affect clinical outcomes. Blimp1 is a transcriptional repressor that controls gene expression changes in B-cell-to-plasmablast transition, which led to silences of $\mathrm{B}$-cell gene expression in PC (59). High Blimp1 expression tends to trigger BC cell invasion and metastasis formation (60). Thus, targeting B-cell transcriptional regulators may further influence BC progression and invasiveness, which reinforces the potential of $\mathrm{B}$ cells as a promising therapeutic target. However, currently, neither 
histopathological features nor conventional biomarkers can be accurately and commonly recognized. The understanding of regulatory mechanisms will aid in predicting clinical outcomes of $\mathrm{BC}$ patients and emerge as a guide to determine the more effective therapies.

\section{AUTHOR CONTRIBUTIONS}

XR designed the review. MS and XR drafted the manuscript and finalized the table and figure. JW provided useful suggestions. All authors read and approved final manuscript.

\section{REFERENCES}

1. Youlden DR, Cramb SM, Dunn NA, Muller JM, Pyke CM, Baade PD. The descriptive epidemiology of female breast cancer: an international comparison of screening, incidence, survival and mortality. Cancer Epidemiol (2012) 36:237-48. doi:10.1016/j.canep.2012.02.007

2. Brown JA, Dorfman DM, Ma FR, Sullivan EL, Munoz O, Wood CR, et al. Blockade of programmed death-1 ligands on dendritic cells enhances T cell activation and cytokine production. J Immunol (2003) 170:1257-66. doi:10.4049/jimmunol.170.3.1257

3. Yamazaki T, Akiba H, Iwai H, Matsuda H, Aoki M, Tanno Y, et al. Expression of programmed death 1 ligands by murine T cells and APC. J Immunol (2002) 169:5538-45. doi:10.4049/jimmunol.169.10.5538

4. Vonderheide RH, Domchek SM, Clark AS. Immunotherapy for breast cancer: what are we missing? Clin Cancer Res (2017) 23:2640-6. doi:10.1158/ 1078-0432.CCR-16-2569

5. Wang ZQ, Milne K, Derocher H, Webb JR, Nelson BH, Watson PH. PD-L1 and intratumoral immune response in breast cancer. Oncotarget (2017) 8:51641-51. doi:10.18632/oncotarget. 18305

6. Brown JR, Wimberly H, Lannin DR, Nixon C, Rimm DL, Bossuyt V. Multiplexed quantitative analysis of $\mathrm{CD} 3, \mathrm{CD} 8$, and $\mathrm{CD} 20$ predicts response to neoadjuvant chemotherapy in breast cancer. Clin Cancer Res (2014) 20:5995-6005. doi:10.1158/1078-0432.CCR-14-1622

7. Song IH, Heo SH, Bang WS, Park HS, Park IA, Kim YA, et al. Predictive value of tertiary lymphoid structures assessed by high endothelial venule counts in the neoadjuvant setting of triple-negative breast cancer. Cancer Res Treat (2017) 49:399-407. doi:10.4143/crt.2016.215

8. Garcia-Martinez E, Gil GL, Benito AC, Gonzalez-Billalabeitia E, Conesa MA, Garcia Garcia T, et al. Tumor-infiltrating immune cell profiles and their change after neoadjuvant chemotherapy predict response and prognosis of breast cancer. Breast Cancer Res (2014) 16:488. doi:10.1186/s13058-014-0488-5

9. Schmidt M, Bohm D, von Torne C, Steiner E, Puhl A, Pilch H, et al. The humoral immune system has a key prognostic impact in node-negative breast cancer. Cancer Res (2008) 68:5405-13. doi:10.1158/0008-5472.CAN07-5206

10. Denkert C, Loibl S, Noske A, Roller M, Muller BM, Komor M, et al. Tumor-associated lymphocytes as an independent predictor of response to neoadjuvant chemotherapy in breast cancer. J Clin Oncol (2010) 28:105-13. doi:10.1200/JCO.2009.23.7370

11. Degnim AC, Hoskin TL, Arshad M, Frost MH, Winham SJ, Brahmbhatt RA, et al. Alterations in the immune cell composition in premalignant breast tissue that precede breast cancer development. Clin Cancer Res (2017) 23:3945-52. doi:10.1158/1078-0432.CCR-16-2026

12. Mahmoud SM, Lee AH, Paish EC, Macmillan RD, Ellis IO, Green AR. The prognostic significance of B lymphocytes in invasive carcinoma of the breast. Breast Cancer Res Treat (2012) 132:545-53. doi:10.1007/s10549011-1620-1

13. Mohammed ZM, Going JJ, Edwards J, Elsberger B, McMillan DC. The relationship between lymphocyte subsets and clinico-pathological determinants of survival in patients with primary operable invasive ductal breast cancer. Br J Cancer (2013) 109:1676-84. doi:10.1038/bjc.2013.493

14. Mao $\mathrm{Y}, \mathrm{Qu} \mathrm{Q}$, Chen $\mathrm{X}$, Huang $\mathrm{O}, \mathrm{Wu}$ J, Shen $\mathrm{K}$. The prognostic value of tumor-infiltrating lymphocytes in breast cancer: a systematic review and

\section{ACKNOWLEDGMENTS}

The authors thank Prof. Shizhen Emily Wang from Department of Pathology, University of California, San Diego, for helpful comments on the manuscript.

\section{FUNDING}

This work was supported by the National Key Technology R\&D Program under Grant number 2015BAI12B12 and the Natural Science Foundation of China under Grant Number 81472471; 81272221.

meta-analysis. PLoS One (2016) 11:e0152500. doi:10.1371/journal.pone. 0152500

15. Xu Y, Lan S, Zheng Q. Prognostic significance of infiltrating immune cell subtypes in invasive ductal carcinoma of the breast. Tumori (2017). doi:10.5301/ tj.5000624

16. Macchetti AH, Marana HR, Silva JS, de Andrade JM, Ribeiro-Silva A, Bighetti S. Tumor-infiltrating CD4+ T lymphocytes in early breast cancer reflect lymph node involvement. Clinics (2006) 61:203-8. doi:10.1590/S180759322006000300004

17. Rody A, Karn T, Liedtke C, Pusztai L, Ruckhaeberle E, Hanker L, et al. A clinically relevant gene signature in triple negative and basal-like breast cancer. Breast Cancer Res (2011) 13:R97. doi:10.1186/bcr3035

18. Karn T, Pusztai L, Holtrich U, Iwamoto T, Shiang CY, Schmidt M, et al. Homogeneous datasets of triple negative breast cancers enable the identification of novel prognostic and predictive signatures. PLoS One (2011) 6:e28403. doi:10.1371/journal.pone.0028403

19. Alistar A, Chou JW, Nagalla S, Black MA, D’Agostino R Jr, Miller LD. Dual roles for immune metagenes in breast cancer prognosis and therapy prediction. Genome Med (2014) 6:80. doi:10.1186/s13073-014-0080-8

20. Nagalla S, Chou JW, Willingham MC, Ruiz J, Vaughn JP, Dubey P, et al. Interactions between immunity, proliferation and molecular subtype in breast cancer prognosis. Genome Biol (2013) 14:R34. doi:10.1186/gb-201314-4-r34

21. Hanker LC, Rody A, Holtrich U, Pusztai L, Ruckhaeberle E, Liedtke C, et al. Prognostic evaluation of the B cell/IL-8 metagene in different intrinsic breast cancer subtypes. Breast Cancer Res Treat (2013) 137:407-16. doi:10.1007/ s10549-012-2356-2

22. Iglesia MD, Vincent BG, Parker JS, Hoadley KA, Carey LA, Perou CM, et al. Prognostic B-cell signatures using mRNA-seq in patients with subtype-specific breast and ovarian cancer. Clin Cancer Res (2014) 20:3818-29. doi:10.1158/1078-0432.CCR-13-3368

23. Guan H, Lan Y, Wan Y, Wang Q, Wang C, Xu L, et al. PD-L1 mediated the differentiation of tumor-infiltrating CD19+ B lymphocytes and $\mathrm{T}$ cells in Invasive breast cancer. Oncoimmunology (2016) 5:e1075112. doi:10.1080/21 62402X.2015.1075112

24. Miligy I, Mohan P, Gaber A, Aleskandarany MA, Nolan CC, Diez-Rodriguez M, et al. Prognostic significance of tumour infiltrating B lymphocytes in breast ductal carcinoma in situ. Histopathology (2017) 71:258-68. doi:10.1111/his. 13217

25. Parkes H, Collis P, Baildam A, Ralphs D, Lyons B, Howell A, et al. In situ hybridisation and S1 mapping show that the presence of infiltrating plasma cells is associated with poor prognosis in breast cancer. Br J Cancer (1988) 58:715-22. doi:10.1038/bjc. 1988.296

26. Mohammed ZM, Going JJ, Edwards J, Elsberger B, Doughty JC, McMillan DC. The relationship between components of tumour inflammatory cell infiltrate and clinicopathological factors and survival in patients with primary operable invasive ductal breast cancer. Br J Cancer (2012) 107:864-73. doi:10.1038/bjc.2012.347

27. Wei H, Fu P, Yao M, Chen Y, Du L. Breast cancer stem cells phenotype and plasma cell-predominant breast cancer independently indicate poor survival. Pathol Res Pract (2016) 212:294-301. doi:10.1016/j.prp.2016.01.008

28. Sobottka B, Pestalozzi B, Fink D, Moch H, Varga Z. Similar lymphocytic infiltration pattern in primary breast cancer and their corresponding 
distant metastases. Oncoimmunology (2016) 5:e1153208. doi:10.1080/21624 02X.2016.1153208

29. Scholl SM, Pallud C, Beuvon F, Hacene K, Stanley ER, Rohrschneider L, et al. Anti-colony-stimulating factor- 1 antibody staining in primary breast adenocarcinomas correlates with marked inflammatory cell infiltrates and prognosis. J Natl Cancer Inst (1994) 86:120-6. doi:10.1093/jnci/86.2.120

30. Lofdahl B, Ahlin C, Holmqvist M, Holmberg L, Zhou W, Fjallskog ML, et al. Inflammatory cells in node-negative breast cancer. Acta Oncol (2012) 51:680-6. doi:10.3109/0284186X.2011.652737

31. Helal TE, Ibrahim EA, Alloub AI. Immunohistochemical analysis of tumorinfiltrating lymphocytes in breast carcinoma: relation to prognostic variables. Indian J Pathol Microbiol (2013) 56:89-93. doi:10.4103/0377-4929.118676

32. West NR, Milne K, Truong PT, Macpherson N, Nelson BH, Watson PH. Tumor-infiltrating lymphocytes predict response to anthracycline-based chemotherapy in estrogen receptor-negative breast cancer. Breast Cancer Res (2011) 13:R126. doi:10.1186/bcr3072

33. Eiro N, Pidal I, Fernandez-Garcia B, Junquera S, Lamelas ML, del Casar JM, et al. Impact of $\mathrm{CD} 68 /(\mathrm{CD} 3+\mathrm{CD} 20)$ ratio at the invasive front of primary tumors on distant metastasis development in breast cancer. PLoS One (2012) 7:e52796. doi:10.1371/journal.pone.0052796

34. Campbell MJ, Baehner F, O’Meara T, Ojukwu E, Han B, Mukhtar R, et al. Characterizing the immune microenvironment in high-risk ductal carcinoma in situ of the breast. Breast Cancer Res Treat (2017) 161:17-28. doi:10.1007/ s10549-016-4036-0

35. Thompson E, Taube JM, Elwood H, Sharma R, Meeker A, Warzecha HN, et al. The immune microenvironment of breast ductal carcinoma in situ. Mod Pathol (2016) 29:249-58. doi:10.1038/modpathol.2015.158

36. Hansen MH, Nielsen HV, Ditzel HJ. Translocation of an intracellular antigen to the surface of medullary breast cancer cells early in apoptosis allows for an antigen-driven antibody response elicited by tumor-infiltrating B cells. J Immunol (2002) 169:2701-11. doi:10.4049/jimmunol.169.5.2701

37. Hansen MH, Nielsen H, Ditzel HJ. The tumor-infiltrating B cell response in medullary breast cancer is oligoclonal and directed against the autoantigen actin exposed on the surface of apoptotic cancer cells. Proc Natl Acad Sci US A (2001) 98:12659-64. doi:10.1073/pnas.171460798

38. Kotlan B, Simsa P, Teillaud JL, Fridman WH, Toth J, McKnight M, et al. Novel ganglioside antigen identified by B cells in human medullary breast carcinomas: the proof of principle concerning the tumor-infiltrating B lymphocytes. J Immunol (2005) 175:2278-85. doi:10.4049/jimmunol.175.4.2278

39. Carmi Y, Spitzer MH, Linde IL, Burt BM, Prestwood TR, Perlman N, et al. Allogeneic IgG combined with dendritic cell stimuli induce antitumour T-cell immunity. Nature (2015) 521:99-104. doi:10.1038/nature14424

40. Li Q, Lao X, Pan Q, Ning N, Yet J, Xu Y, et al. Adoptive transfer of tumor reactive B cells confers host T-cell immunity and tumor regression. Clin Cancer Res (2011) 17:4987-95. doi:10.1158/1078-0432.CCR-11-0207

41. Xia Y, Tao H, Hu Y, Chen Q, Chen X, Xia L, et al. IL-2 augments the therapeutic efficacy of adoptively transferred B cells which directly kill tumor cells via the CXCR4/CXCL12 and perforin pathways. Oncotarget (2016) 7:60461-74. doi:10.18632/oncotarget.11124

42. Fremd C, Stefanovic S, Beckhove P, Pritsch M, Lim H, Wallwiener M, et al. Mucin 1-specific B cell immune responses and their impact on overall survival in breast cancer patients. Oncoimmunology (2016) 5:e1057387. doi:10.1080/2 162402X.2015.1057387

43. von Mensdorff-Pouilly S, Verstraeten AA, Kenemans P, Snijdewint FG, Kok A, Van Kamp GJ, et al. Survival in early breast cancer patients is favorably influenced by a natural humoral immune response to polymorphic epithelial mucin. J Clin Oncol (2000) 18:574-83. doi:10.1200/JCO.2000. 18.3.574

44. Gheybi E, Salmanian AH, Fooladi AAI, Salimian J, Hosseini HM, Halabian R, et al. Immunogenicity of chimeric MUC1-HER2 vaccine against breast cancer in mice. Iran J Basic Med Sci (2018) 21:26-32. doi:10.22038/IJBMS.2017. 25686.6335

45. Yanaba K, Bouaziz JD, Haas KM, Poe JC, Fujimoto M, Tedder TF. A regulatory $\mathrm{B}$ cell subset with a unique CD1dhiCD5+ phenotype controls $\mathrm{T}$ cell-dependent inflammatory responses. Immunity (2008) 28:639-50. doi:10.1016/j.immuni.2008.03.017
46. Olkhanud PB, Damdinsuren B, Bodogai M, Gress RE, Sen R, Wejksza K, et al. Tumor-evoked regulatory B cells promote breast cancer metastasis by converting resting CD4(+) T cells to T-regulatory cells. Cancer Res (2011) 71:3505-15. doi:10.1158/0008-5472.CAN-10-4316

47. Tao H, Lu L, Xia Y, Dai F, Wang Y, Bao Y, et al. Antitumor effector B cells directly kill tumor cells via the Fas/FasL pathway and are regulated by IL-10. Eur J Immunol (2015) 45:999-1009. doi:10.1002/eji.201444625

48. Zhang Y, Eliav Y, Shin SU, Schreiber TH, Podack ER, Tadmor T, et al. B lymphocyte inhibition of anti-tumor response depends on expansion of Treg but is independent of B-cell IL-10 secretion. Cancer Immunol Immunother (2013) 62:87-99. doi:10.1007/s00262-012-1313-6

49. Zhang Y, Morgan R, Podack ER, Rosenblatt J. B cell regulation of anti-tumor immune response. Immunol Res (2013) 57:115-24. doi:10.1007/ s12026-013-8472-1

50. Zhang Y, Morgan R, Chen C, Cai Y, Clark E, Khan WN, et al. Mammarytumor-educated B cells acquire LAP/TGF-beta and PD-L1 expression and suppress anti-tumor immune responses. Int Immunol (2016) 28:423-33. doi:10.1093/intimm/dxw007

51. Rowley DA, Stach RM. B lymphocytes secreting IgG linked to latent transforming growth factor-beta prevent primary cytolytic $\mathrm{T}$ lymphocyte responses. Int Immunol (1998) 10:355-63. doi:10.1093/intimm/10.3.355

52. Hagn M, Schwesinger E, Ebel V, Sontheimer K, Maier J, Beyer T, et al. Human $\mathrm{B}$ cells secrete granzyme $\mathrm{B}$ when recognizing viral antigens in the context of the acute phase cytokine IL-21. J Immunol (2009) 183:1838-45. doi:10.4049/ jimmunol.0901066

53. Ruffell B, Au A, Rugo HS, Esserman LJ, Hwang ES, Coussens LM. Leukocyte composition of human breast cancer. Proc Natl Acad Sci U S A (2012) 109:2796-801. doi:10.1073/pnas.1104303108

54. Tang Y, Jiang Q, Ou Y, Zhang F, Qing K, Sun Y, et al. BIP induces mice CD19(hi) regulatory B cells producing IL-10 and highly expressing PD-L1, FasL. Mol Immunol (2016) 69:44-51. doi:10.1016/j.molimm.2015. 10.017

55. Shalapour S, Font-Burgada J, Di Caro G, Zhong Z, Sanchez-Lopez E, Dhar D, et al. Immunosuppressive plasma cells impede T-cell-dependent immunogenic chemotherapy. Nature (2015) 521:94-8. doi:10.1038/nature14395

56. Muenst S, Schaerli AR, Gao F, Daster S, Trella E, Droeser RA, et al. Expression of programmed death ligand 1 (PD-L1) is associated with poor prognosis in human breast cancer. Breast Cancer Res Treat (2014) 146:15-24. doi:10.1007/ s10549-014-2988-5

57. Nanda R, Chow LQ, Dees EC, Berger R, Gupta S, Geva R, et al. Pembrolizumab in patients with advanced triple-negative breast cancer: phase Ib KEYNOTE-012 study. J Clin Oncol (2016) 34:2460-7. doi:10.1200/JCO.2015. 64.8931

58. Buisseret L, Garaud S, de Wind A, Van den Eynden G, Boisson A, Solinas C, et al. Tumor-infiltrating lymphocyte composition, organization and PD-1/ PD-L1 expression are linked in breast cancer. Oncoimmunology (2017) 6:e1257452. doi:10.1080/2162402X.2016.1257452

59. Minnich M, Tagoh H, Bonelt P, Axelsson E, Fischer M, Cebolla B, et al. Multifunctional role of the transcription factor Blimp-1 in coordinating plasma cell differentiation. Nat Immunol (2016) 17:331-43. doi:10.1038/ ni.3349

60. Sciortino M, Camacho-Leal MDP, Orso F, Grassi E, Costamagna A, Provero P, et al. Dysregulation of Blimp1 transcriptional repressor unleashes p130Cas/ ErbB2 breast cancer invasion. Sci Rep (2017) 7:1145. doi:10.1038/s41598017-01332-z

Conflict of Interest Statement: The authors declare that the research was conducted in the absence of any commercial or financial relationships that could be construed as a potential conflict of interest.

Copyright (c) 2018 Shen, Wang and Ren. This is an open-access article distributed under the terms of the Creative Commons Attribution License (CC BY). The use, distribution or reproduction in other forums is permitted, provided the original author(s) and the copyright owner are credited and that the original publication in this journal is cited, in accordance with accepted academic practice. No use, distribution or reproduction is permitted which does not comply with these terms. 